\title{
建築構造用耐火鋼を使用した鋼管コンクリート柱の 耐火性能に関する実験的研究

\author{
EXPERIMENTAL STUDY ON FIRE RESISTANCE OF CONCRETE-FILLED \\ STEEL TUBULAR COLUMNS USING FIRE-RESISTANT STEEL
}

\author{
作. 本好文*1, 山口種美*2, 岡田忠義*3, 吉田正友*4, 田坂茂樹*5 \\ Yoshifumi SAKUMOTO, Tanemi YAMAGUCHI, Tadayoshi OKADA, \\ Masatomo YOSHIDA and Shigeki TASAKA
}

\begin{abstract}
This paper presents experimental results of full-scale loaded heat tests and small-size heat tests of concrete-filled steel tubular columns (CFST columns) using Fire-Resistant steel (FR steel). By covering the tube surface with protection having lower insulation property, CFST columns could get longer fire resistance time by its heat capacity of the inner concrete and could resist to the bending moment caused by eccentric load without reinforcement by keeping the steel temperature lower than $600^{\circ} \mathrm{C}$.

Ceramic type protection, foaming type intumescent coating, gypsum plaster board, ceramic fiber and wet rockwool were used for the protection material.
\end{abstract}

Keywords : fire resistance, steel, high temperature, column, concrete, fire protection 耐火, 鋼材, 高温, 柱, コンクリート, 被覆

\section{1.まえがき}

鋼管コンクリート柱 (Concrete-Filled Steel Tube, 以下，CFST 柱）は，鋼管の内部にコンクリートを充 填し; 鋼とコンクリートの合成効果により荷重支持能力 や変形性能を向上させた合成柱であるが，耐火性能につ いても，一般の鋼管柱と比較して優れている。

欧州では，CFST，柱も含めた各種合成柱の䩂火性能 に関する研究が実験的・解析的に行われ ${ }^{11,2)}$, 耐火被覆

(以下，被覆）をなくす，あるいは軽減できる酎火設計 手法が実用化されている3!。

図一1に無被覆の CFST 柱の模式図を示す。無被覆 のCFST 柱が標準加熱曲線（各国とも JIS A 1304 とほ ぼ同じ)および要求耐火時間に基づいた加熱を受けると, 鋼管が高温となり荷重支持能力を失うことから，コンク リートと補強鉄筋により鉄筋コンクリート柱として荷重 を支持することとなる。ここで, 補強鉄筋は, 主として 偏心荷重によって生じる曲げモーメントに抵抗する目的 で挿入される。

我が国においても，CFST 柱の耐火性能に関する研
究が近年数多く実施されている(4) が，このような設計 法は実用化に至っていない。これは，我が国では，一般 的に柱・梁接合部には耐震用のダイヤフラムが設けら れ，配筋が困難であることが理由のひとつと考えられる。 本研究は, 高温強度が従来の一般構造用鋼材 · (以下, 一般鋼）と比較して高く, 鋼材温度 $600^{\circ} \mathrm{C}$ における 0.2 $\%$ 耐力が常温時規格值の $2 / 3$ 以上 (長期許容応力度) を有する建築構造用耐火鋼?（FR 鋼：Fire Resistant Steel)を鋼管に使用した CFST 柱の耐火性能について,

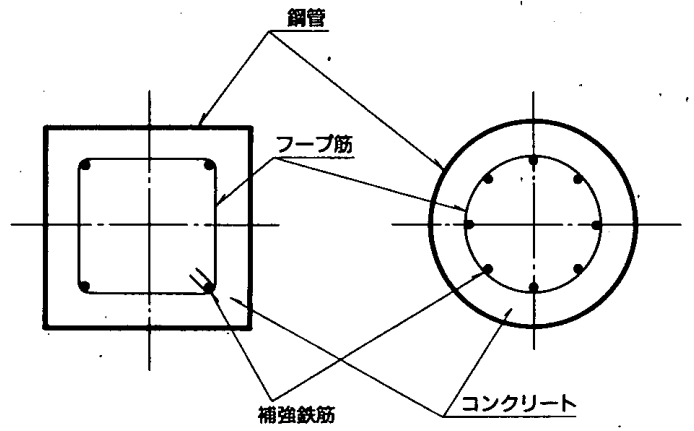

図一1 CFST 柱の模式図

\footnotetext{
*1 新白本製鐵株式会社・工修

*2 新日本製鐵株式会社・工修

*3,新日本製鐵株式会社・工博

*4 日本建築総合試験所·工修

*5 日本建築総合試験所
}

Nippon Steel Corp., M. Eng.

Nippon Steel Corp., M. Eng.

Nippon Steel Corp., Dr. Eng.

General Building Research Corp., M. Eng.

General Building Research Corp. 
載荷加熱試験により実験的に研究したものである ${ }^{81 \sim 10) 。}$ FR 鋼の CFST 柱は，鋼管を被覆することで鋼材温度 を $600^{\circ} \mathrm{C}$ 以下，すなわち鋼管が長期許容応力度に相当 する荷重を支持できる温度以下で使用することとし，補 強鉄筋なしで上記の曲げモーメントに抵抗する柱であ る。なお，比較を目的に一般鋼の CFST 柱の載荷加熱 試験も合わせて実施した。

被覆材料は，水酸化アルミニウム・炭酸カルシウム・ セメント系被覆 (厚さ $5 \mathrm{~mm}$, 以下, セラミック被覆) と耐火塗料（屋内用発泡性・ドイツ製）を使用した。こ れらの被覆はいずれも要求耐火時間 1 時間の性能に満た ない軽微なものであるが，鋼管への直線の入熱を避ける ことで，コンクリートの熱容量を有効に利用でき，鋼管 温度の上昇が少なく長時間の耐火性能が得られる。

CFST 柱の熱容量については，上記の被覆材料に， 無機繊維強化石高ボード (以下, 石裔ボード)，セラミッ クファイバー，湿式ロックウール（以下，ロックウール） を加えた 5 種類で, 被覆厚さをパラメーターとした加熱 試験を実施し，その効果を検証した”1”。

なお，載荷加熱試験および加熱試験は，各々，日本建 築総合試験所の柱用，床梁用加熱試験炉で実施した。

\section{2. 載荷加熱試験}

\section{1 試験体および試験条件}

試験体は，角型鋼管（FR 鋼のおよび一般鋼の SM $490 \mathrm{~A}, \square-300 \times 300 \times 9$, 長さ $3500 \mathrm{~mm}$ ) に普通コンク リートを充填したものである。試験体の形状および寸法 を図一 2 に示す。鋼管には，コンクリートの水蒸気爆裂 防止用に蒸気抜き孔（直径 $25 \mathrm{~mm}$ ）を 26 力所設けた。 鋼管およびコンクリートの機械的性質を表一 1,2 に，コ ンクリートの組成を表一 3 に示す。

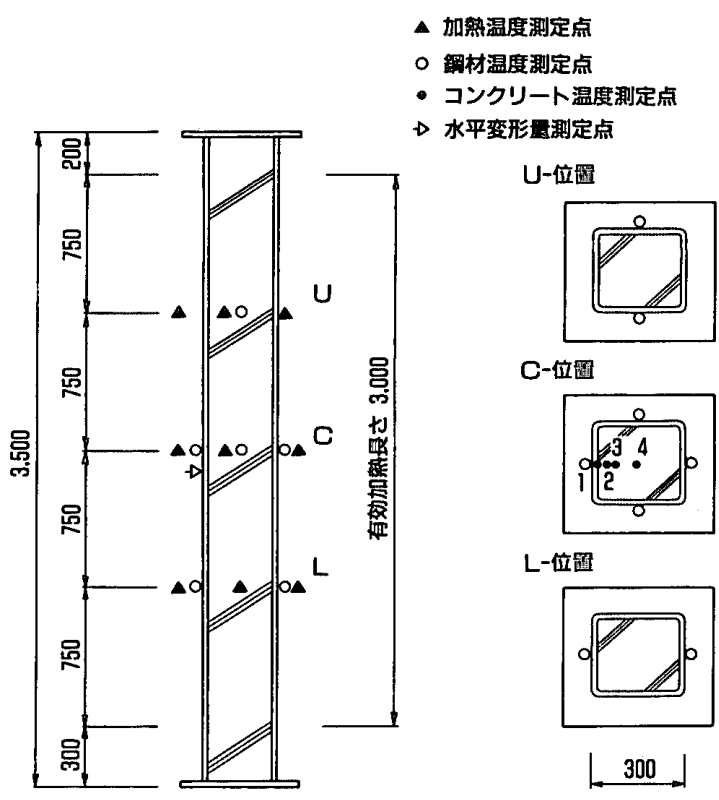

図一2 載荷加熱試験の試験体の形状・寸法
表一1 鋼管の機械的性質

\begin{tabular}{|c|c|c|c|c|}
\hline 鋼 種 & $\begin{array}{c}\text { 温 } \\
\left({ }^{\circ} \mathrm{C}\right)^{\circ}\end{array}$ & $\begin{array}{c}\text { 降 伏 点 } \\
\left(\mathrm{kgf} / \mathrm{cm}^{2}\right)\end{array}$ & $\begin{array}{c}\text { 引張強麇 } \\
\left(\mathrm{kgf} / \mathrm{cm}^{2}\right)\end{array}$ & $\begin{array}{c}\text { 伸 U゙ } \\
(\%)\end{array}$ \\
\hline \multirow{2}{*}{ 一般鋼鋼管 } & 常温 & 3680 & 5380 & 24 \\
\cline { 2 - 5 } & 600 & 1340 & 1990 & 60 \\
\hline \multirow{2}{*}{ F R 鋼鋼管 } & 常温 & 3650 & 5450 & 24 \\
\cline { 2 - 5 } & 600 & 2220 & 3300 & 46 \\
\hline
\end{tabular}

表一2 コンクリートの機械的性質

\begin{tabular}{|c|c|c|c|c|}
\hline & $\begin{array}{c}\text { 压縮強度 } \\
\left(\mathrm{kgf} / \mathrm{cm}^{2}\right)\end{array}$ & $\begin{array}{c}\text { 引镸強度 } \\
\left(\mathrm{kgf} / \mathrm{cm}^{2}\right)\end{array}$ & $\begin{array}{c}\text { ヤング率 } \\
\left(\mathrm{kgf} / \mathrm{cm}^{2}\right)\end{array}$ & $\begin{array}{c}\text { 含 水 率 } \\
(\%)\end{array}$ \\
\hline 一般鋼鋼管 & 392 & 31.5 & $2.93 \times 10^{5}$ & 4.4 \\
\hline F R 鋼鋼管 & 382 & 29.5 & $3.01 \times 10^{5}$ & 4.9 \\
\hline
\end{tabular}

表一3 コンクリートの組成

\begin{tabular}{|c|c|c|c|c|c|}
\hline 水セメント比 & \multicolumn{5}{|c|}{ 単位容積 質量 $\left(\mathrm{kg} / \mathrm{m}^{3}\right)$} \\
\hline$(\%)$ & 粗骨材 & 細骨材 & 水 & セメント & A E滅水剤 \\
\hline 33.5 & 1068 & 585 & 171 & 510 & 1.275 \\
\hline
\end{tabular}

試験条件を表一 4 に示す。試験体数は，鋼種，被覆の 有無, 種別, 載荷荷重および載荷方法（中心載荷，偏芯 載荷)をパラメーターとした 9 体である。ここで，載荷 荷重 $N$ （軸力）は，式（1）によった。

$$
N=\eta \times\left(\sigma_{\mathrm{y}} \times A_{s}+F_{\mathrm{c}} \times A_{c}\right)
$$

ここで，各項は以下のとおりである。

$\eta:$ 軸力比

$\sigma_{y} ：$ 鋼材の常温時降伏点 $($ 表一 1$)$

$F_{c}$ : コンクリートの常温時圧縮強度 (表一2)

$A_{s}$ : 鋼管断面積 $\left(104.76 \mathrm{~cm}^{2}\right)$

$A_{c}:$ コンクリート断面積 $\left(795.24 \mathrm{~cm}^{2}\right)$

軸力比は，鋼管とコンクリートの累加強度（鋼管の降 伏点およびコンクリートの圧縮強度に相当する荷重）に 対する比率で，0.2，0.3をベースとした。また，表一4 に示した $N /\left(F_{c} \times A_{c}\right)$ は，コンクリート缩強度に対す る載荷荷重の比率である。なお，常温時の鋼管とコンク リートの軸力の分担は，鋼管：約 $55 \%$ ，コンクリート : 約 $45 \%$ であった。

偏芯量は, 柱断面の 1 方向に柱幅の $10 \%(30 \mathrm{~mm})$ とした。この值は, 偏芯量をパラメーターとした研究” で規準値として採用された值である。偏芯量の大小の影 響は，本研究の範囲に含んでいない。

被覆材には，セラミック被覆と耐火塗料を使用した。 セラミック被覆の組成を表一 5 に示す。耐火凗料はアル キド系で，錆止層（塗布量 $150 \mathrm{~g} / \mathrm{m}^{2} \times 1$ 層）・発泡層 $\left(900 \mathrm{~g} / \mathrm{m}^{2} \times 2\right.$ 層) ・保護層 $\left(200 \mathrm{~g} / \mathrm{m}^{2} \times 1\right.$ 層) 加ら構成 されている。全体の塗膜厚は表一 4 に示した。 
表一4 載荷加熱試験（試験条件・試験結果）

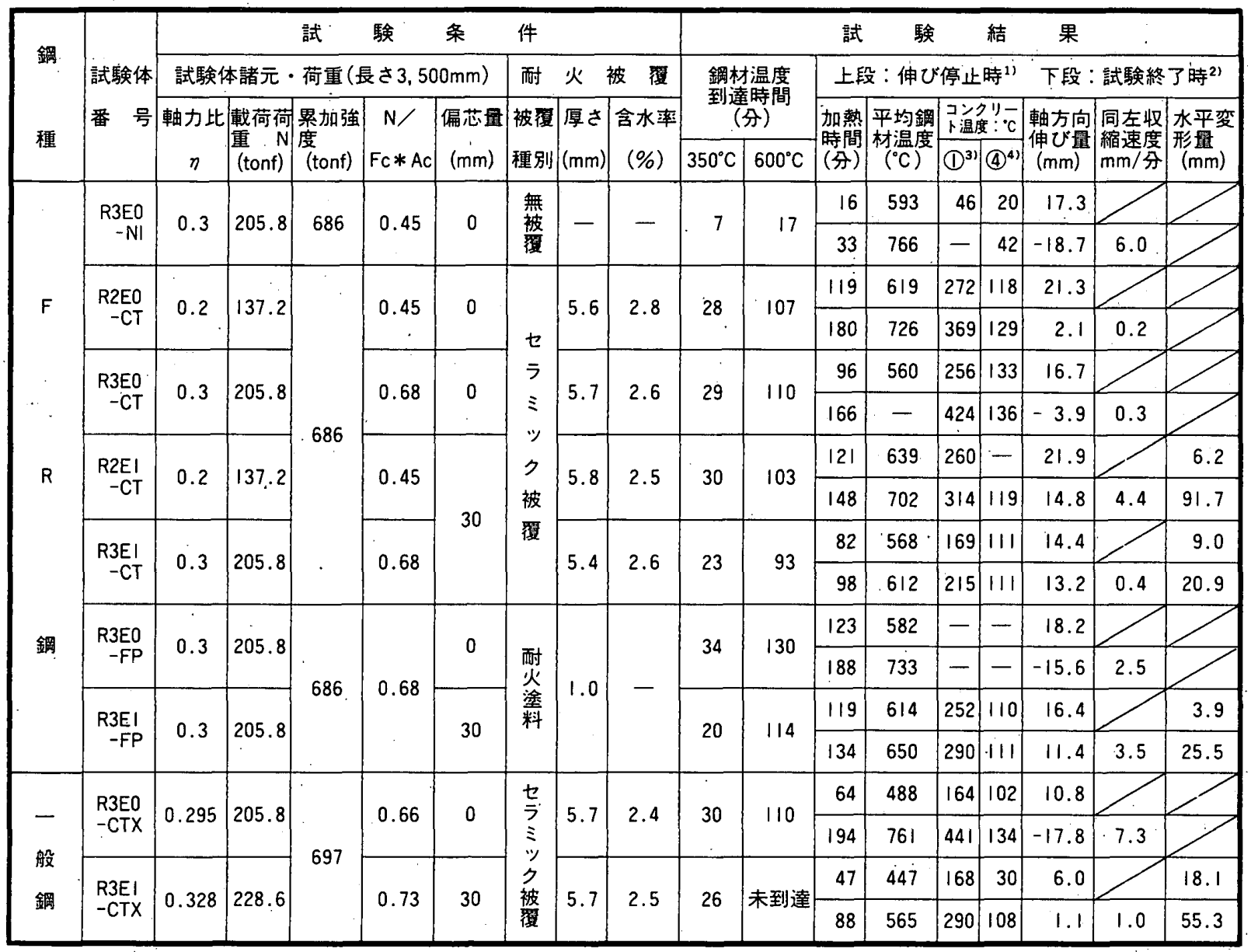

1）最大秆びに達した時点 2）荷重を支持できなくなった時点 3）鋼管付近 4）コンクリート中央

表一5，被覆材料の組成＼cjkstart単位：重量\%

\begin{tabular}{|c|c|c|c|c|c|c|}
\hline 材料名称 & $\begin{array}{l}\text { ロック } \\
\text { ウール }\end{array}$ & $\begin{array}{l}\text { セメン } \\
\text { ト }\end{array}$ & $\begin{array}{l}\text { バーミ } \\
\text { キュラ } \\
\text { イト }\end{array}$ & $\begin{array}{l}\text { アルミ } \\
\text { ナシジ } \\
\text { カ }\end{array}$ & 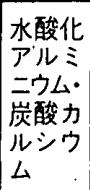 & 乥の他 \\
\hline セラミック被覆 & - & 20 & 10 & 35 & 30 & 5 \\
\hline 湿式ロックウール & 30 & 20 & 10 & 10 & - & 30 \\
\hline セラミックファイパー & - & - & - & 100 & - & - \\
\hline
\end{tabular}

\section{2 試験方法}

試験装置を図一 3 に示す。載荷装置は, アムスラー式 圧縮試験機（容量 300 tonf ·定荷重装置付），ロードセ ルおよび反カフレームにより構成されており，表一 4 に 記載した荷重を加熱前に試験体に加えた。上下の載荷板 には球座 (半径 $190 \mathrm{~mm}$ ) を設置しており, 座屈長さは 試験体長さと同じである。

座屈長さ (3500 mm) は一般のビル建築の柱と比べ て長いが，試験装置の構造上，端部を固定にできないこ と, 試験体の長さを短くすると加熱炉内で試験体が分割 されることとなり, 試験体の設置・取り出しが困難であ ること（加熱炉の開口は上部のみ）など, 試験装置の制

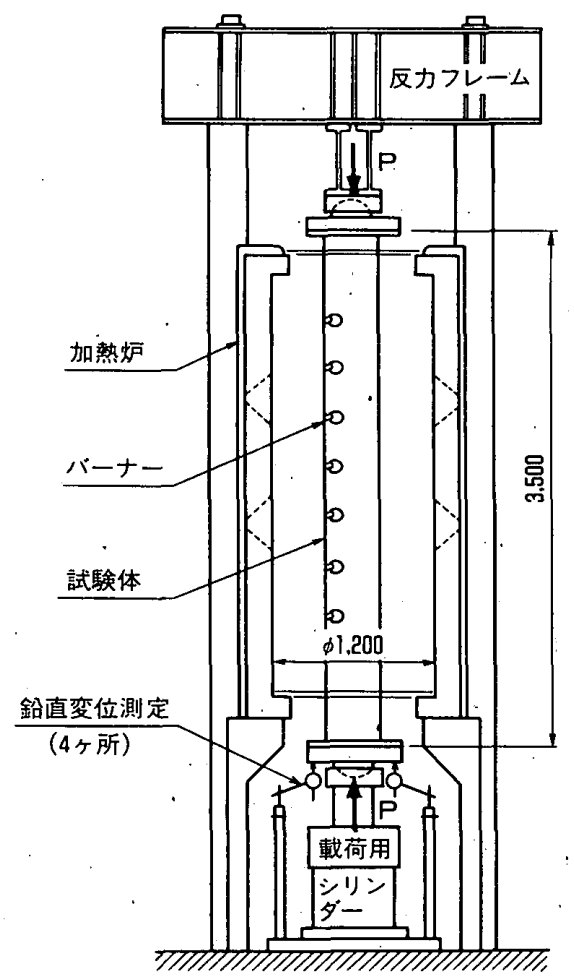

図一3 載荷加熱試験装置 
約からこの長さとした。

載荷の終了は, 試験体が荷重支持能力を失った（以下, 崩壊) 時点とし, その判定は軸方向変形速度 (収縮速度) が急增した時点 (以下, 試験終了時) とした。載荷終了 と同時に加熱も終了した。なお，加熱はJIS A $1304 に$ 準拠した標準加熱とした。

試験中の試験体の伸びと鋼管の局部座屈による急激な 収縮を把握するため, 試験体全体の伸び量を柱脚部ベー スプレートの 4 隅に変位計（感度 $: 100 \mu / \mathrm{mm}$ ) を設置 して測定した。なお，偏芯載荷の試験体では，柱中央部 の水平変形量をセラミック棒（長さ $1 \mathrm{~m}$, 直径 $10 \mathrm{~mm}$ ) を使用して炬外に取り出し, 変位計 (感度 : $100 \mu / \mathrm{mm}$ ) で測定した。各測定点を図一2に示す。

加熱温度は, JIS C 1602 に規定する $\mathrm{K}$ 熱電対を保護 管に入れ, 試験体より $3 \mathrm{~cm}$ 離れた位置で材長方向に 3 力所各 4 点の計 12 点で測定した。また，鋼管温度は 材長方向に 3 力所の計 8 点, コンクリート温度は, 材長 方向中央部の 4 点とした。各測定点を図一 2 に示す。

\section{3 試験結果}

試験結果を表一4に示す。本表には，鋼管温度が $350^{\circ} \mathrm{C}$ および $600^{\circ} \mathrm{C}$ に到達した加熱時間（以下，時間）, 柱の伸びが停止した時点（以下，伸び停止時）および試 験終了時の時間と各部温度, 軸方向伸び量, 同収縮速度, 水平変形量を記載した。

\subsection{1 温度性状}

図一 4 に鋼管の平均温度を, 図一 5,6 にコンクリート 温度（鋼管付近と中央部）を，加熱温度と合わせて示し た。図中の丸印は，試験終了時を示している。

試験体 R3E0-CT では，鋼管用の熱電対が時間 115 分ですべて破断した。また，試験体 R 3E0-NIでは鋼管 近辺のコンクリート用の熱電対が破断し，いずれも，試 験終了時まで温度を測定できなかった。試験体 R3E0-NIにおける熱電対の破断は，コンクリートの破 壊が進行したことによるものと考えられる。試験体 R3E0-CT では, 中心部のコンクリート温度が時間 70 ～95 分の間で低下しているが, これは内部の水蒸気の 移動の影響と考えられる。

無被覆の試験体 R 3E0-NI では, 鋼管温度は加熱温度 にほぼ等しく急激に上昇している。被覆した試験体では， 鋼管温度は $300 \sim 400^{\circ} \mathrm{C}$ まで急激に上昇し, その後上昇 速度は鈍化している。これは, 耐火塗料が鋼材温度 $300^{\circ} \mathrm{C}$ 近辺で発泡した後断熱性を発揮することも要因の ひとつであるが, CFST 柱の熱容量が時間とともに発 揮され，鋼管温度の上昇が抑制されたものと考えられる。 なお，鋼管温度の上昇速度は各試験体ともほぼ同じで， セラミック被覆（被覆厚 $5 \mathrm{~mm}$ ) と耐火塗料（塗膜厚 1 $\mathrm{mm})$ はほぼ同等の断熱性能を有している。

伸び停止時の鋼管温度は, FR 鋼の試験体で軸力比

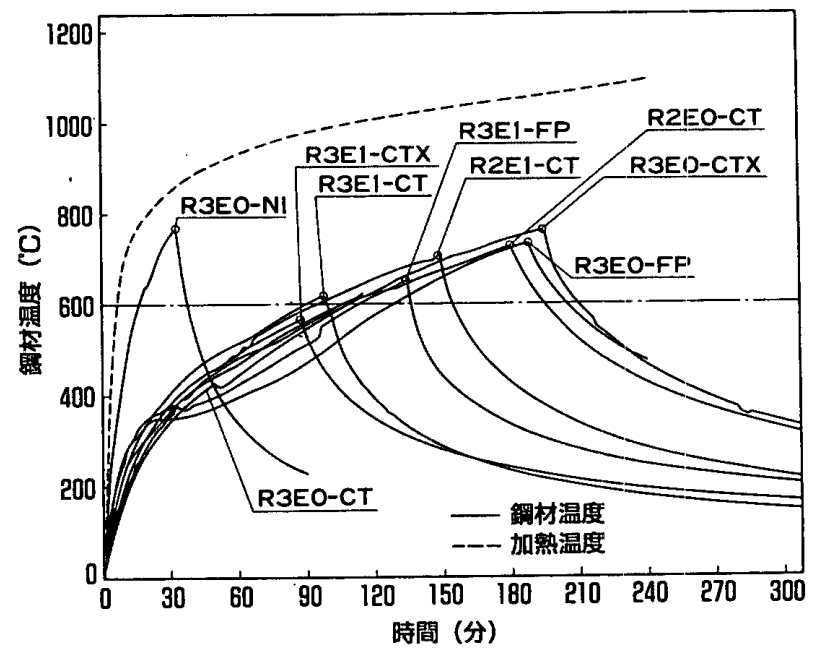

図一4 加熱時間と鋼材温度 (平均値) との関係

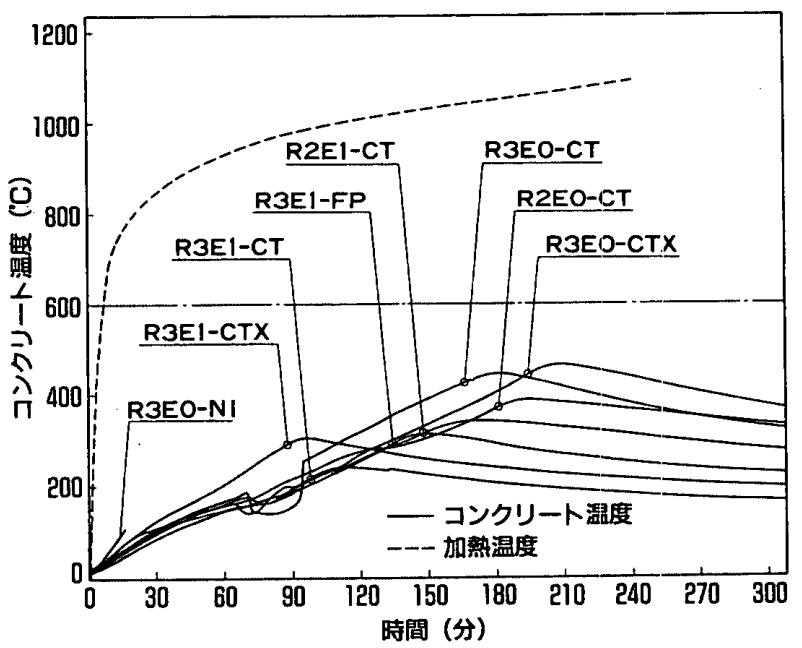

図一5 加熱時間とコンクリート温度（鋼管付近）との関係

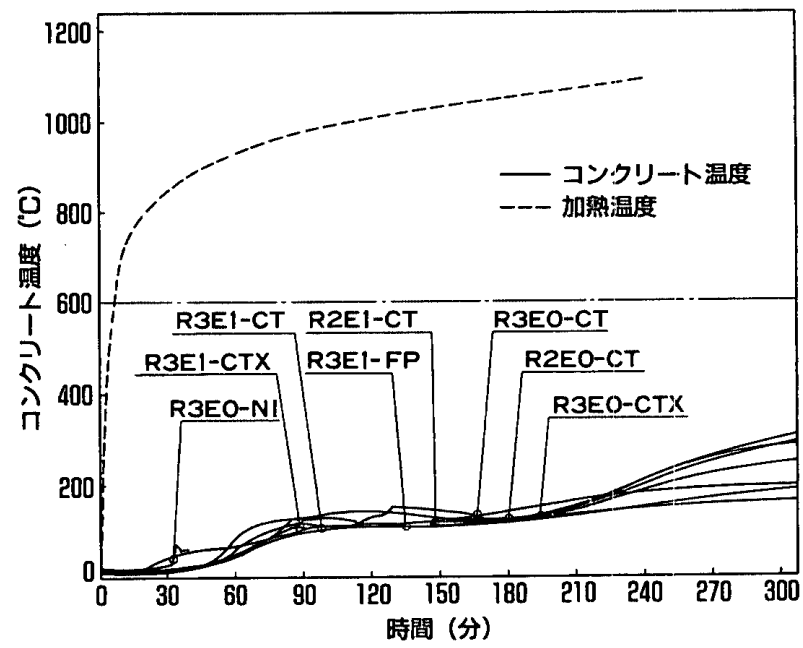

図一6 加熱時間とコンクリート温度 (中央部) との関係

0.2 では $600^{\circ} \mathrm{C}$ を上回り, 軸力比 0.3 では試験体 $\mathrm{R} 3 \mathrm{E}$ 1-FP を除いて $600^{\circ} \mathrm{C}$ を下回っている。一方，一般鋼の 試験体ではいずれも $500^{\circ} \mathrm{C}$ を下回っている。

試験終了時の鋼管温度は, FR 鋼の試験体でいずれも 
$600^{\circ} \mathrm{C}$ を上回っており，一般鋼では，偏芯載荷の $\mathrm{R} 3 \mathrm{E}$ 1-CTX で $600^{\circ} \mathrm{C}$ を下回っている。

コンクリート温度はいずれも低く, 試験終了時で, 鋼 管近辺で最高 $441^{\circ} \mathrm{C}$ ，中心部で最高 $136^{\circ} \mathrm{C}$ であった。 2.3.2: 変形性状

時間と軸方向伸び量の関係を, 中心載荷の試験体につ いては図一7（伸び量は 4 点の平均值）に，偏芯載荷の 試験体は図一8（伸び量は各点ごと）に示した。また, 偏芯載荷の試験体の, 時間之柱中央部の水平変形量との 関係を図一9に示した。

図一7 から, 中心載荷の試験体における変形性状は, 以下の 4 ステージに分類できる（模式図：図一10）。

(1) 柱が熱膨張する第 1 ステージ（伸び停止時まで）

(2) 鋼管に局部座屈 (写真一1，2）が生じ，柱が急激に 収縮する第 2 ステージ

(3) 鋼管の局部座屈により，鋼管からコンク!ートに軸 力が移行し，収縮速度が遅くなる第 3 ステージ

(4) コンクリートの強度低下で再び急激に収縮し，崩壊 に至る第 4 ステージ

第 2 ステージでは，鋼管とコンクリートの温度差から 鋼管の熱膨張にコンクリートが追従できず，コンクリー 卜が負担していた軸力が鋼管に移ること，また，鋼管そ のものが高温で強度低下を起こすことから, 局部座屈が 生じる。局部座屈が発生する時点は, 伸び停止後, 収縮 速度が急增する時点と考えられ，特に，FR 鋼の試験体 において顕著に表れている。局部座屈の発生した時間お よび鋼管温度は, R3E0-NI：18 分 $\left(624^{\circ} \mathrm{C}\right)$, R2E0CT : 140 分 $\left(653^{\circ} \mathrm{C}\right)$, R3E0-CT : 113 分 $\left(613^{\circ} \mathrm{C}\right)$, R3E0-FP： 137 分 $\left(622^{\circ} \mathrm{C}\right)$ などであり，鋼管温度は いずれも $600^{\circ} \mathrm{C}$ を超えている。 $\mathrm{FR}$ 鋼の $600^{\circ} \mathrm{C}$ におけ る降伏点（表一1）は $2220 \mathrm{kgf} / \mathrm{cm}^{2}$ であることから， 例えば，軸力比 0.3 の試験体では，この時点で鋼管がす べての軸力を負担する状態（鋼管の応力度は, $N / A_{s}=$ $\left.1960 \mathrm{kgf} / \mathrm{cm}^{2}\right)$ に近くなっていると考えられる。なお, 一般鋼のR3E0-CTX では，伸び停止時の時間が短く, また；収縮速度も比較的緩やかであることから，局部座 屈の発生点が明確ではない。

第 3ステージで収縮速度が遅くなる時間は, R 3E 0$\mathrm{NI}: 20$ 分, R2E0-CT : 145 分, R3E0-CT : 118 分, R3E0-FP：142 分, R3E0-CTX： 95 分などであった。

第 4 ステージにおける試験終了時の時間とコンクリー 卜強度との関連については，本研究では明らかにできな かった。なお，試験体R2E0-CT は時間が 180 分に到 達しても荷重を支持したことから，180 分で試験を中止 した。これは，軸力比が小さく $(0.2)$ ，コンクリート強 度が高温時低下しても荷重を支持したものと考えられ る。

偏芯載荷の試験体では，鋼管に局部座屈が生じると曲



図一7 軸方向伸び量（中心載荷)

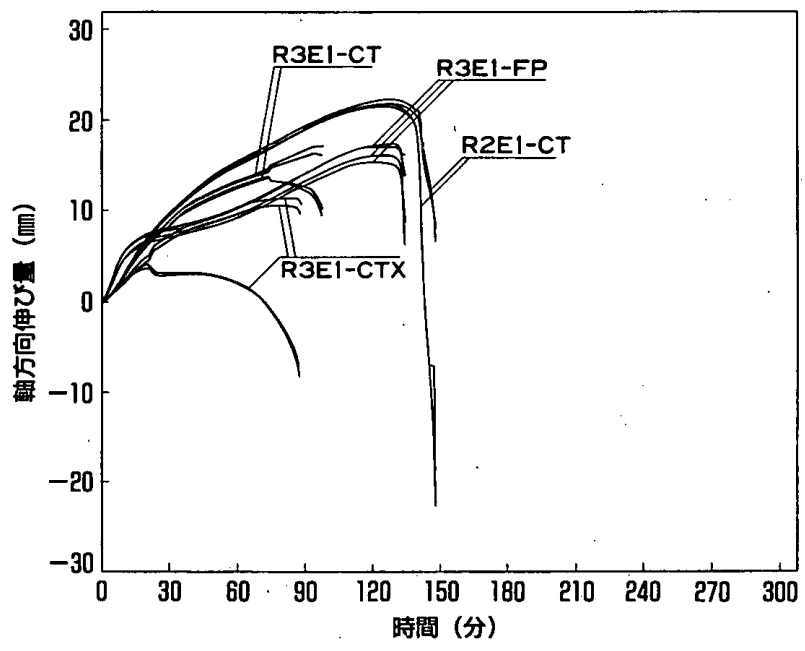

図一8 軸方向伸び量（偏芯載荷）

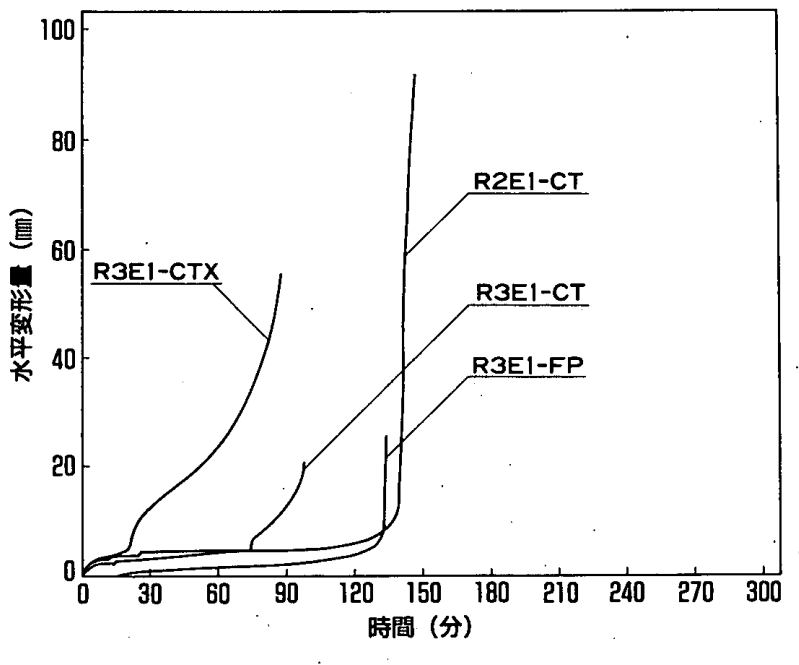

図一9 水平方向変形量（偏芯載荷）

げモーメントに抵抗できないことから第 3 ステージが存 在せず（模式図：図一10), 鋼管の局部座屈が直接崩壊 につながっている（図一8における試験体R2E1-CT, R3E1-FP)。なお，試験体 R3E1-CT とR3E1-CTX 


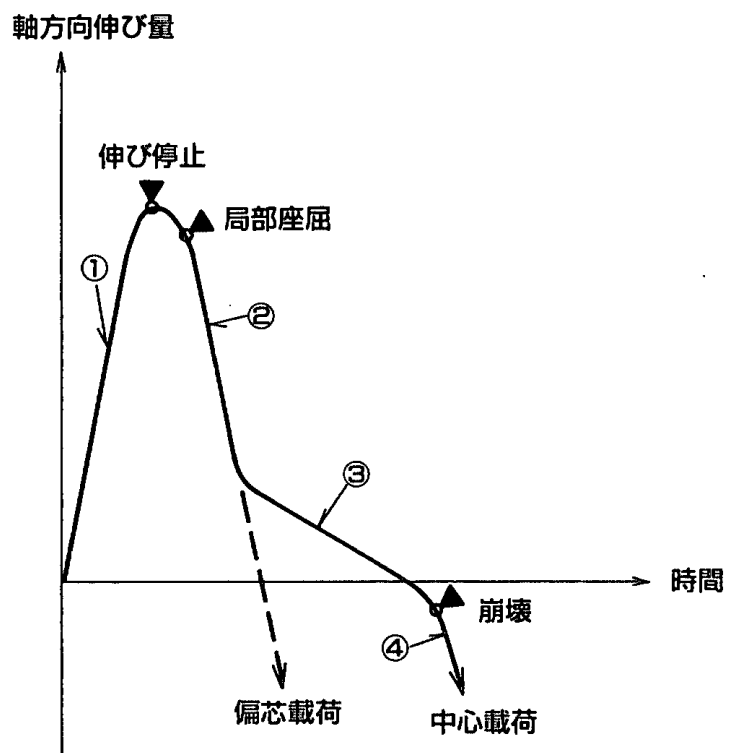

図一10 変形性状の模式図

では, ベースプレートの 4 隅で測定した軸方向伸び量が 試験途中で 2 本ずつに分離しており, 第 3 ステージが明 確に表れていない。これは，R3E1-CT で 75 分前後, R3E1-CTXで 22 分前後に載荷装置下部の球座が回転 し，4隅に設置した変位計が伸びと収縮を測定したこと による (いずれも伸び停止前)。このことは, 図一8で 伸び量が分離した時点と, 図一9で水平変形量の増加し た時点とが，試験体R3E1-CT とR3E1-CTXにおい て一致していることからも明らかである。球座の回転が, 伸び停止時, 試験終了時の時間に及ぼした影響は明らか ではないが, 4 点の伸び量の平均值が最大に達した時点 （伸び停止時）は，

R3E1-CT:82 分 (試験終了時：98 分)

R3E1-CTX：47 分 (試験終了時：88 分)

などであり (表一4), 伸び停止時之試験終了時の時間差
が短い試験体R3E1-CT は，試験体R2E1-CT，R3E 1-FP と同様の変形性状と考えられる。なお，一般鋼の R3E1-CTX では，伸び停止時の時間が短く，第 3 ス テージの存在が明確ではない。

一般鋼の試験体は, 中心載荷, 偏芯載荷乞も網材温度 $350^{\circ} \mathrm{C}$ 近辺から伸びが鈍化し, 最大伸び量も FR 鋼と比 較して，例えば，中心載荷の武験体（R3E0-CT とR3 E 0-CTX) では $2 / 3$ 程度と小さくなっており，伸び停 止時の時間も短くなっている。伸びが鈍化した理由は, 一般鋼の強度が鋼材温度の上昇とともに低下し，环縮ひ ずみの増大により伸びが相殺されたものと洘えられる。

\section{3 .3 崩壊状況}

崩壊状況を, 写真一 1,2 (中心載荷：R3E(1-NI）お よび写真一3（偏芯載荷：R2E1-CT) に示した。

中心載荷の試験体では, 全体座屈は生じておらず, 鋼 管の局部座屈部分におけるコンクリートの破壊で柱が荷 重支持能力を失ったものと考えられる。なお，無被覆の 試験体では䤡管の損傷が著しい。

偏芯載荷の試験体では，柱の全体変形（軸方向収縮お よび横たわみ）が著しい。なお，座屈の起点は鋼管の局 部座屈部分である。

\section{3 .4 考 察}

軸力比と時間の関係を, 伸び停止時および試験終了時 について図一11，12 にそれぞれ示す。以上の結果から， 各パラメーターの影響を以下に考察する。

(1) 被覆の有無

無被覆の試験体では鋼管温度が急激に上昇するが, 被 覆した試験体では，伸び停止時および試験終了時の時間 が大幅に伸びている。

(2) 偏芯の影響

偏芯載荷の試験体は，中心載荷と比較すると伸び停止

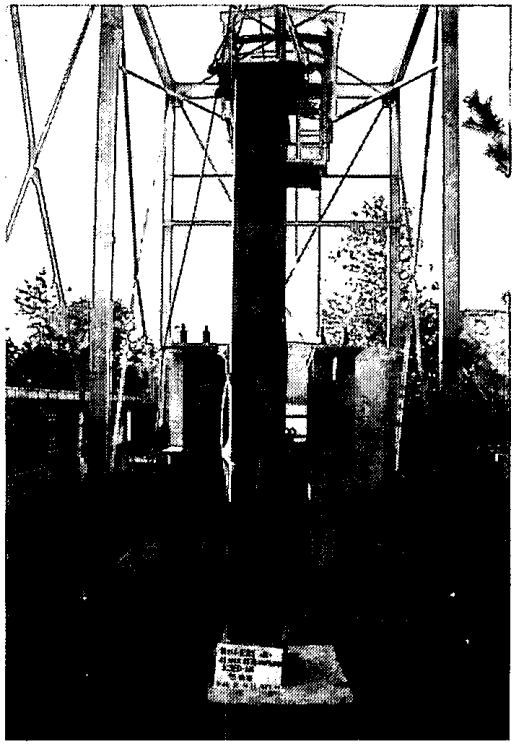

写真一1 崩壊後の試験体（R3E0-NI）

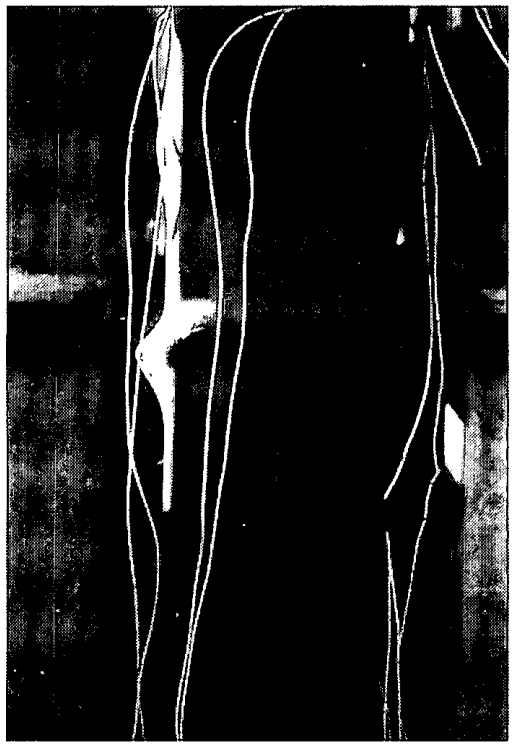

写真一2 局部座屈の試験体 (R3E0-NI)



写真一3 崩壊後の試験俶（R.2E1-CT) 


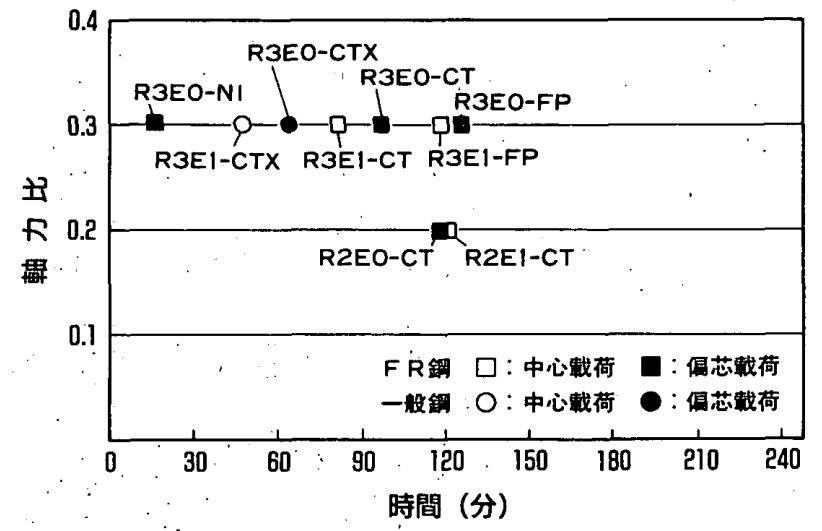

図一11，軸力比之耐火時間の関係（伸び停止時）

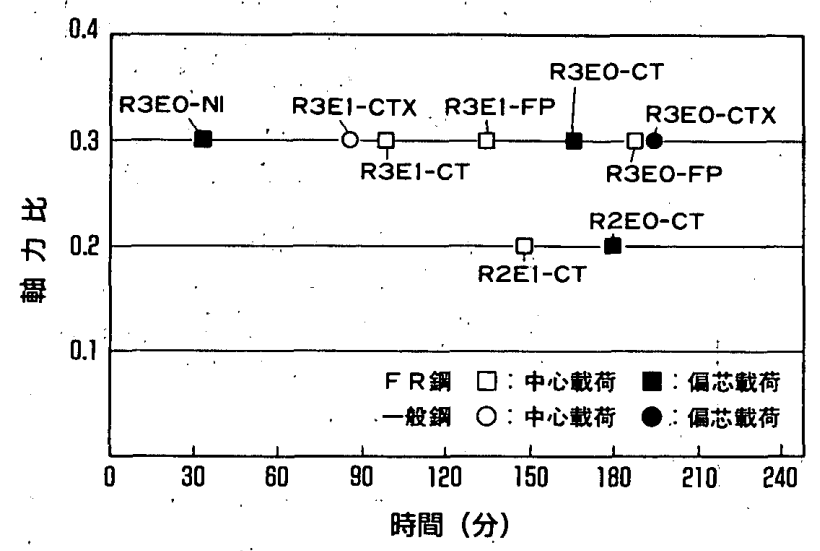

図一12 軸力比と酎火時間の関係（試験終了時）

時の時間に大きな差はないが, 試験終了時の時間が大幅 に短い。試験終了時と伸び停止時の時間の比率は,

中心載荷：FR 鋼 $1.51 \sim 1.73 ， 一$ 般鋼 3.03

偏芯載荷：FR 鋼 1.13 1.22, 一般鋼 1.87

であった（無被覆の試験体 R 3E0-NI を除く）。このこ とは, 補強鉄筋のない CFST 柱が偏芯載荷を受けると, 伸び停止後（あるいは局部座屈発生後）短時間で崩壊に 至り, 偏芯載荷に敏感であることを示している。なお, FR 鋼の試験体は一般鋼と比較して試験終了時と伸び停 止時の時間の比率が短いが，これは，一般鋼の伸び停止 時が短く, '相対的に試験終了時との比率が大きくなった ことによると考えられる。

\section{(3) 軸力の影響}

軸力が増加すると, 伸び停止時および試験終了時の時 間が短くなる。その比率は,

中心載荷：R2E0-CT/R3E0-CT

伸び停止時，1.24, 試験終了時 1.08

偏芯載荷：R2E1-CT/R3E1-CT

伸び停止時 1.48 , 試験終了時 1.51

などであり，偏芯載荷においてその影響が大きい。

(4) 鋼種の影響

FR 鋼は一般鋼と比較して; 伸び停止時の時間が 1.5 〜 1.7 倍（約 30 分）と長いが, これは, 伸び停止時が
鋼管が荷重支持能力を保持している時点であることか ら, 高温強度に優れた FR 鋼が一般鋼と比較して時間 が延びているものである。試験終了時の時間に大きな差 は認められない。なお，鋼管温度が $600^{\circ} \mathrm{C}$ に到達する 時間は, $350^{\circ} \mathrm{C}$ に到達する時間のいずれも 3 倍以上と なっている(表一4)。これは, CFST 柱の熱容量が時 間とともに発揮され, 鋼管温度の上昇速度が遅くなるこ とによると考えられる。

(5) 座屈長さの影響

坐屈長さは一定としており，その影響は明らかではな いが, 偏芯載荷の試験終了時の時間を除いて大きな差は ないと考えられる。

伸び停止時には, 偏芯載荷の試験体も含めて全体座屈 は生じておらず座屈長さの影響はない。これは, 偏芯載 荷における水平変形量の測定結果などからも明らかであ る。

一方; 試験終了時については, 中心載荷では, 試験体 の崩壊状況から全体座屈は生じていないと判断される (写真一1，2)。また, 偏芯載荷においても, 全体座屈 が発生する前に破壊の起点 (局部座屈) 汃形成されてい ること (写真一 3$)$, 鋼管が角形であり局部座屈後にコン クリートを拘束する力が小さいことなどから, 中心載荷 と同様, 鋼管の局部座屈部分におけるコンクリートの破 壊で柱の荷重支持能力が決まっだものと考えられるが, 本研究の結果からは明らかではない。

\section{3. 熱容量試験}

3.1 試験体および試験条件

試験体は，角形鋼管（ $\square-300 \times 300 \times 9$ ，長さ $450 \mathrm{~mm}$ ) に普通コンクリートを充填したものである。試験体の形 状および寸法を図一13に示す。

試験条件を表一6に示す。試験体数は, 被覆の有無, 種別および厚さをパラメーターとした 12 体である。被 覆材料は, 載荷加熱試験で使用したセラミック被覆と耐 火塗料に加えて, 石亳ボード（JIS A 6913, 比重：750 $\left.\mathrm{kg} / \mathrm{m}^{3}\right)$, 七ラミックファイバー (JIS R 3311, 比重 :

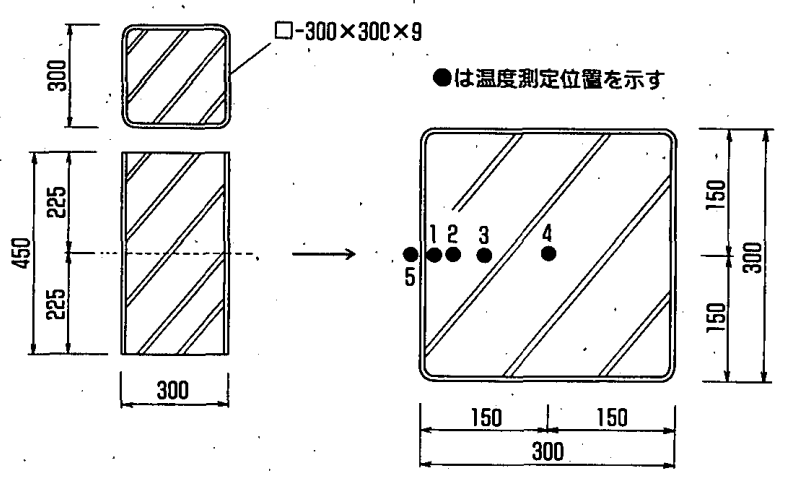

図一13 熱容量試験の試験体の形状・寸法 
表一6 熱容量試験（試験条件・試験結果）

\begin{tabular}{|c|c|c|c|c|c|c|}
\hline \multirow{2}{*}{$\begin{array}{l}\text { 試験体 } \\
\text { 番 号 }\end{array}$} & \multirow{2}{*}{ 被 得 材 料 } & \multirow{2}{*}{$\begin{array}{c}\text { 被㙏厚 } \\
(\mathrm{mm})\end{array}$} & \multicolumn{2}{|c|}{ 指定被覆厚 $(\mathrm{mm})$} & \multicolumn{2}{|c|}{ 鋼材温度到達時間(分) } \\
\hline & & & １時間 & 2 時間 & $350^{\circ} \mathrm{C}$ & $600^{\circ} \mathrm{C}$ \\
\hline $\begin{array}{l}A-12 \\
A-15\end{array}$ & 無機栱維強化石高ボード & $\begin{array}{l}12 \\
15\end{array}$ & 21 & $\begin{array}{c}42 \\
\text { (2 層) }\end{array}$ & $\begin{array}{r}65 \\
120\end{array}$ & $\begin{array}{l}160 \\
\text { 未到達 }\end{array}$ \\
\hline $\begin{array}{l}B-10 \\
B-13\end{array}$ & 屋内用発泡性酎火塗料 & $\begin{array}{l}1.0 \\
1.3\end{array}$ & - & - & $\begin{array}{l}30 \\
35\end{array}$ & $\begin{array}{l}115 \\
160\end{array}$ \\
\hline $\begin{array}{l}c-03 \\
c-06\end{array}$ & セラミックファイバー & $\begin{array}{l}3 \\
6\end{array}$ & $\stackrel{-}{(+ロ ッ ク ~}$ & $\begin{array}{c}15 \\
-ル 45)\end{array}$ & $\begin{array}{l}55 \\
80\end{array}$ & $\begin{array}{l}120 \\
160\end{array}$ \\
\hline $\begin{array}{l}D-05 \\
D-15\end{array}$ & 湿式ロッククール & $\begin{array}{r}5 \\
15\end{array}$ & 30 & 40 & $\begin{array}{r}70 \\
145\end{array}$ & $\begin{array}{l}\text { 未到達 } \\
\text { 未到達 }\end{array}$ \\
\hline $\begin{array}{l}E-05 \\
E-10 \\
E-15\end{array}$ & セラミック被覆 & $\begin{array}{r}5 \\
10 \\
15\end{array}$ & 20 & 30 & $\begin{array}{l}30 \\
58 \\
93\end{array}$ & $\begin{array}{l}105 \\
170 \\
\text { 未到達 }\end{array}$ \\
\hline$x-00$ & （無被覆） & - & - & $\cdots$ & 10 & 25 \\
\hline
\end{tabular}

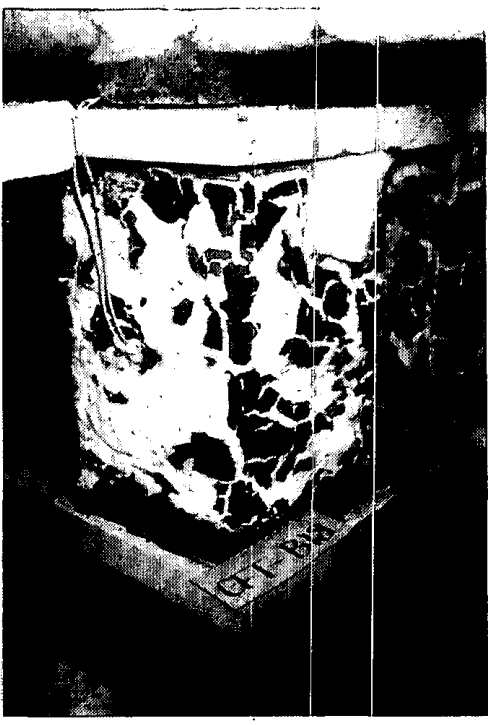

写真一4 熱容量試験体：藏験後 (耐火塗料, B-18)

（試験体記号 B-18）

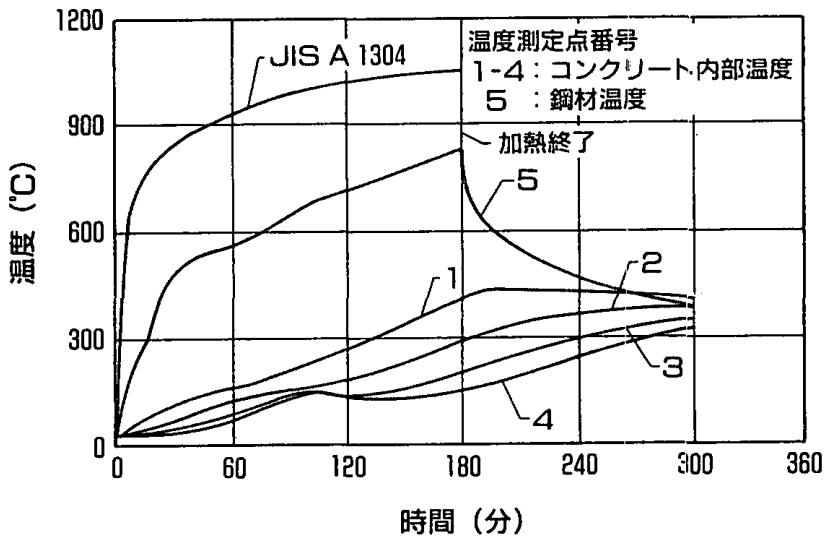

図一14 熱容量試験結果

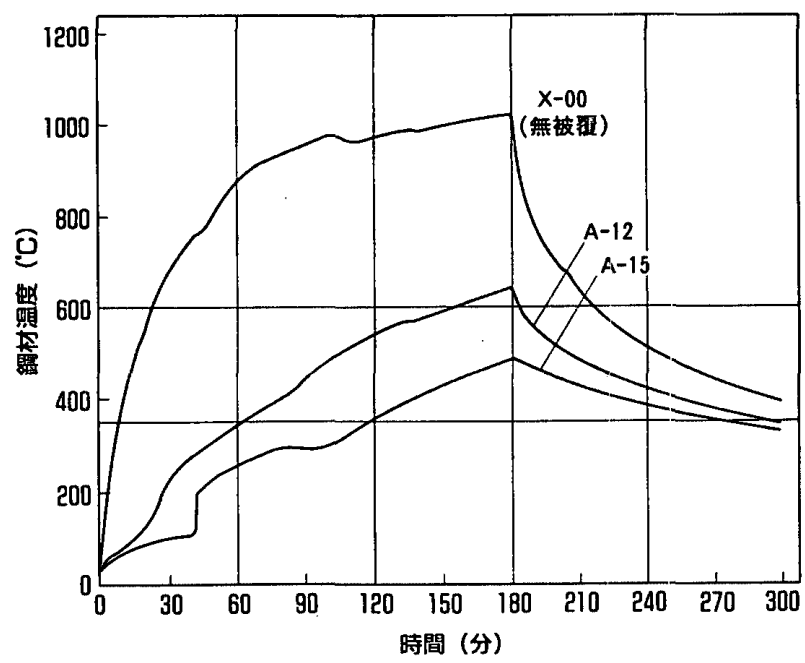

図一15鋼材温度測定值（石高ボード）

CT 20, 同：10,15, $20 \mathrm{~mm}$ ) である。なお，載荷加熱 試験では，試験終了時で加熱を停止していることから， 鋼材温度もその時点から低下している。本た, 図中の一 点鎖線は, 前述の CFST 柱の載荷加熱試験で測定した 




図一16 鋼材温度测定值（耐火塗料）

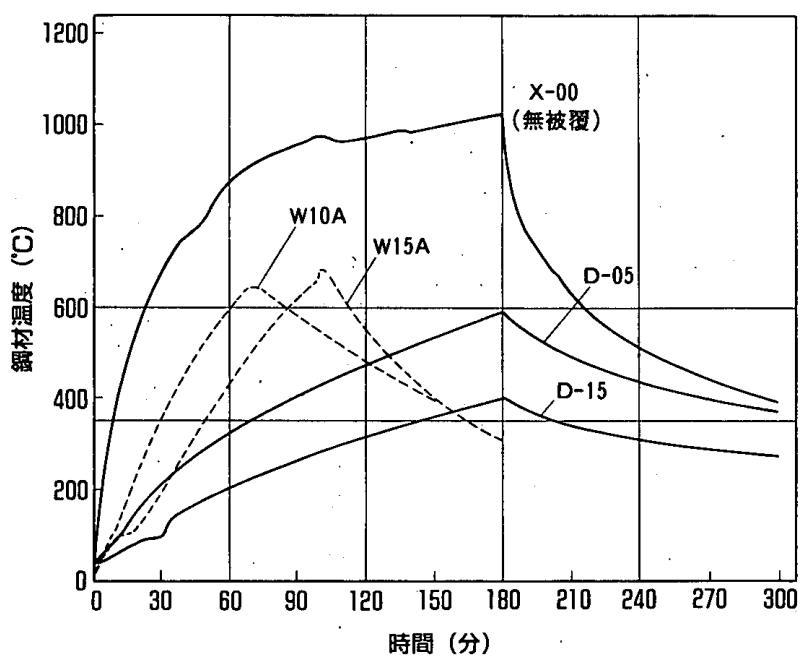

図一18 鋼材温度測定值（湿式ロックウール）

鋼管温度 (平均値) で, 被覆は, 耐火塗料 (R3E0-FP), セラミック被覆（R3E0-CT）である。なお，無被覆 の試験体（X-00）の鋼管温度も合わせて示した。

表一6に，鋼管温度が $350^{\circ} \mathrm{C}$ および $600^{\circ} \mathrm{C}$ に到達し た時間を記載した。表中の未到達は, $600^{\circ} \mathrm{C}$ に到達せず 3 時間加熱で式験を終了したものである。また, 耐火構 造の指定材料については, 耐火時間 1, 2 時間の被覆厚 を参考に記載した。指定材料の被覆厚は; 鉄骨柱 $(\mathrm{H}-300$ $\times 300 \times 10 \times 15$, 上述の載荷加熱試験と同じ）で鋼材温 度 $350^{\circ} \mathrm{C}$ に到達する厚さであることから，CFST 柱と の此較上, 参考とした。

以下に, 試験結果について考察する。

同一被覆厚のロックウール (図一18, D-15 と W $15 \mathrm{~A}$, 被覆厚 $15 \mathrm{~mm}$ ) およびセラミック被覆（図一19, E-10 と CT 10, 被覆厚 $10 \mathrm{~mm}$ ) では, CFST 柱の鋼管温度 の上昇速度が鉄骨柱のほぼ $1 / 2$ 程度である。また, 耐火 塗料 (図一16) でも, 塗膜厚の薄い CFST 柱が (B-10, $1.0 \mathrm{~mm})$ が厚い鉄骨柱 (PI 48, 2.58 mm) より温度上

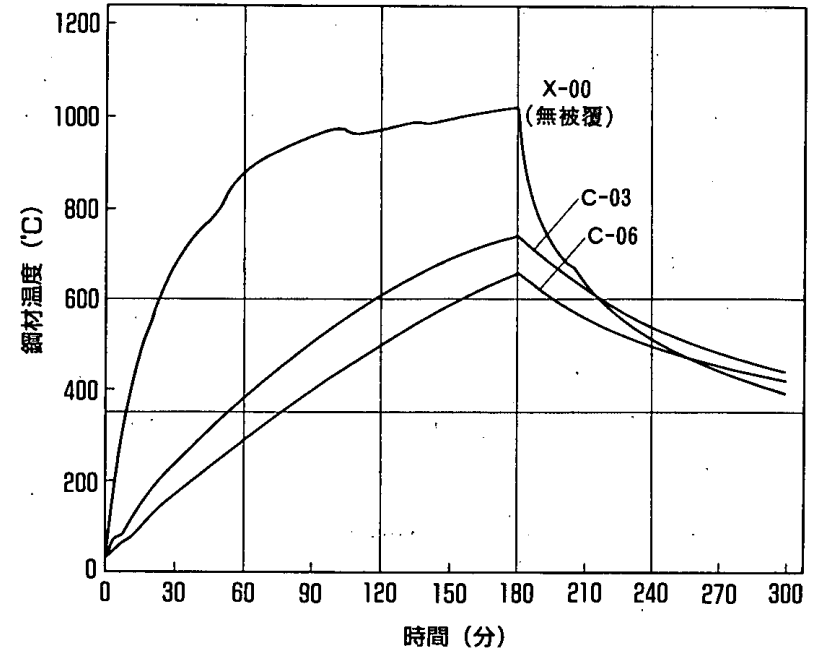

图一17鋼材温度測定值（セラミックファイバー）

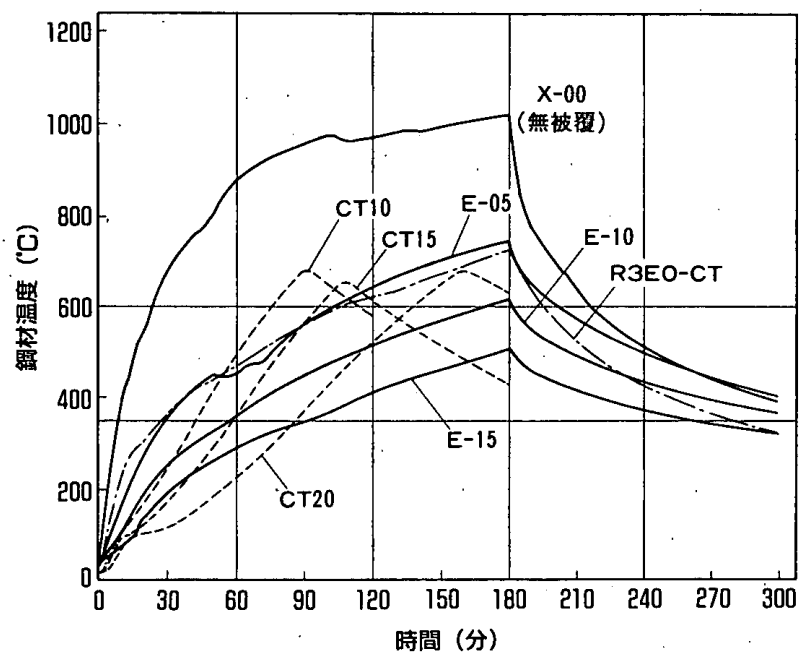

図一19鋼材温度測定值（セラミック被覆）

昇が少ない。

なお，前章で述べた載荷加熱試験における鋼管温度の 測定結果亡本加熱試験の結果を比較すると, 同一被覆厚 では, 耐火塗料（図一16，R3E0-FP と B-10, 塗膜厚 $1.0 \mathrm{~mm}$ ), セラミック被覆 (図一19, R 3E 0-CT と E-05, 被覆厚 $5 \mathrm{~mm}$ ) の温度上昇はほぼ等しい。

その他の試験結果についても，鋼管温度が $350^{\circ} \mathrm{C} に$ 到達した時間と表一 6 に示した各被覆の指定厚の比較か ら, CFST 柱の熱容量の効果は明らかである。なお, 指定厚は, 加熱試験において加熱終了後の温度上昇も含 めて鋼材温度が $350^{\circ} \mathrm{C}$ 以下となる厚さであり，本試験 は 3 時間まで加熱を継続していることから, 厳密な比較 とはなっていない。

以上の結果から, CFST 柱では，その熱容量から鎆 管温度の上昇が少なく, 各被覆材料とも鉄骨柱と比較し てほぼ $1 / 2$ の被覆厚で同等の断熱性能が得られる。

また，鋼材温度が $600^{\circ} \mathrm{C}$ に到達する時間は $350^{\circ} \mathrm{C}$ に 到達する時間のいずれも 2 倍以上となっている(表一6)。 
これは, CFST 柱の熱容量が時間とともに発揮され, 鋼材温度が高温となった時点で温度上昇が緩やかになる ことによるもので，FR 鋼を使用することの効果が明ら かとなっている。

\section{4. 結 語}

以上, CFST 柱の載荷加熱試験および加熱試験（熱 容量試験）の結果から, 以下の点が明らかとなった。 (1) 補強鉄筋のない CFST 柱は偏芯載荷に敏感である。 すなわち, 伸び停止時 (あるいは鋼管の局部坐屈発生時) から試験終了時 (崩壊時) までの時間が, 中心載荷と比 較して大幅に短い。また，軸力が増加すると伸び停止時・ 試験終了時とも時間が短くなるが, 偏芯載荷においてそ の影響が顕著である。なお，以上は，本研究で対象とし た座屈長さの試験体における結果であり，座屈長さが短 い試験体では異なった結果が得られることも考えられ る。

(2) 無被覆の CFST 柱では鋼管温度が急激に上昇する ことから，特に，伸び停止時（あるいは局部座屈発生時） の時間が極めて短くなる。一方, 鋼管に軽微な被覆を行 えば, CFST 柱の熱容量が有効に発揮され, 伸び停止 時・試験終了時とも時間が大幅に延びる。

(3) CFST 柱の熱容量の効果は時間とともに発揮され ることから，高温において鍼材温度の上昇が緩やかとな る。このことは，高温強度に䋷れたFR 鋼を使用する ことで,その効果を有効に利用できることを示している。

以上, 補強鉄筋のないCFST 柱は偏芯載荷に敏感で あることから，安定した耐火性能を得るには，鋼管が， 荷重を支持できる温度（伸び停止時あるいは局部座屈発 生時まで）で使用することが望ましい。この場合，鋼管 に軽微な被覆を行うことで, CFST 柱の熱容量を有効 に発揮させ，長時間の耐火性能が得られる。さらに，鋼 管に高温強度に優れた FR 鋼を使用することで，その 耐火性能を大幅に向上させることができる。

\section{謝 辞}

本研究の遂行にご協力頂いた新日鐵化学の片島 昭 氏, 原 基氏，エスケー化研の元木英男氏に謝意を表し ます。

\section{参考文献}

1) K. Kordina and W. Klingsch : Fire Safety of Composite Columns of Concrete Filled Hollow Sections, CIDECT
Report, No. 15, C 1/C 2, 1983

2) J.P. Grimault : Calcul a l'incendie des profils creux remplies de béton, manual pratique. Chambre Syndicale des fabricants du tubes d'acier. (和訳 : JSSC レ ポート, No. 10, 1988)

3) Calculation of the Fire Resistance of Centrally Loaded Composite Steel-Concrete Columns Exposed to the Standard Fire. ECCS, Technical Committee 3, 1988. 9. (和訳：JSSC レボート, No.18, 1991)

4）㧧藤 光, 上杉英樹：鋼管コンクリート柱の耐火性（充 媜コンクリートの有効性), 日本建築学会大会学術講演梗 概集, pp. 2107 -2108, 昭和 52 年 10 月

5）鈴木敏郎, 木村 衛, 古平章夫, 伏見光雅 : コンクリ一 卜充てん角形鋼管柱の耐火性能に関する実験（定軸力下 における加熱時挙動について), 日本建築学会論文報告集, 第 350 号, pp. $77 \sim 85,1985.4$

6）木村 衛, 太田秀彦, 金子洋文, 古平章夫：複合荷重を 受ける充填型鋼管コンクリート柱の耐火性能に関する実 験的研究, 日本建築学会論文報告集, 第 417 号, pp. 63 $\sim 70,1990.11$

7) 作本好文, 大橋 守, 計良光一郎, 斎藤 光: 建築構造 用酎火鎆材の高温強度特性, 日本建築学会諭文報告集, 第 427 号, pp. $107 \sim 115,1991.9$

8）岡田忠義, 吉田正友, 田坂茂樹, 計良光一郎, 作本好文, 山口種美 : 建築構造用耐火鋼材を使用したコンクリート 充垣鎆管実大柱の載荷加熱試験（その2, 七ラミック系 耐火被䘘材を使用した場合)，日本建築学会大会学術講演 梗概集，pp. 1171～1172，1991.9.

9) 岡田忠義, 吉田正友, 田坂茂樹, 岡部 猛, 作本好文, 山口種美：建築構造用耐火鋼材を使用したコンクリート 充填鋼管柱の耐火性能, GBRC, 第 65 号, pp. 18 23, 1992.1

10) T. Okada, T. Yamaguchi, Y. Sakumotı and K. Keira, : Loaded Heat Tests of Full-Scale Columns of ConcreteFilled Tubular Steel Structure using Fire-Resistant Steel for Buildings, Proceedings of the Third International Cooperation and Research in Steel-Concrete Composite Structures, pp. 101 106, 1991.9

11）雑喉良介, 吉田正友, 田坂茂樹, 作本好文, 山口種美, 岡田忠䕰：建築構造用耐火鋼材を使用するコンクリート 充填鋼管柱の熱容量特性に関する実験研究, 日本建築学 会大会学術講演梗概集, pp. 1403 1404, 1992. 8

12）作本好文, 山口種美, 岡田忠韹, 吉田正友, 田坂茂樹, 斎藤 光：建築構造用耐火鋼材の耐火性能に関する実験 的研究, 日本建築学会論文報告集, 第 434 号, pp. 149 $158,1992.4$

（1992 年 9 月 9 日原稿受理，1993 年 2 月 8 日採用决定） 